\title{
Dlouhověkost jako nová otázka sociálních věd'
}

\author{
Longevity as a New Issue in the Social Sciences
}

Michaela Honelová, Marcela Petrová Kafková

\begin{abstract}
Longevity represents, in the sociology of aging, and not only in the Czech Republic, a relatively new and little considered topic. Due to the significant increase in long-life in developed countries, including the Czech Republic, the issue is substantial. This article aims to support the discussion of longevity issues in the social sciences in the Czech environment. Above all it focuses on introducing the concept of resilience as a possible explanation for the longevity of some and the disability of other older adults. It seems that this originally psychological concept offers a satisfactory explanation of the determinants and factors of increasing longevity and its distinct diversity. For example, current knowledge seems to indicate that the higher longevity of women can be explained by their higher resilience, typically mobilized after widowhood.
\end{abstract}

KEY WORDS longevity, resilience, perseverance, ageing, active ageing, population ageing

V různých kulturních tradicích lze najít množství historek a bájí o lidech, kteří se údajně dožívali vysokého věku či dosáhli dokonce nesmrtelnosti, avšak až do roku 1800 nelze s největší pravděpodobností najít jedince, který by se dožil věku 100 let či více (Vaupel a Kitowski 2009: 40). Tento fakt byl zaprŕíčněn jak vysokou kojeneckou úmrtností tak také značnou úmrtností na infekční choroby, které zabíjely osoby v průběhu celého životního běhu. $\mathrm{V}$ posledních desetiletích však dochází $\mathrm{k}$ výraznému prodlužování délky lidského života spojeného s demografickým stárnutím společností. Tento jev zasahuje různou měrou všechny státy světa. Z demografického hlediska je nárůst střední délky života způsoben postupným zlepšováním ekonomických a sociálních podmínek jedinců, medicínským pokrokem a obecně lepšími životními podmínkami, což přineslo a nadále přináší prodlužování délky života. Díky všem zmíněným determinantám dochází v jednotlivých státech nejen k prodlužování střední délky života, ale také ke zlepšení kvality života jedinců, a to i v pozdějším věku (Riley 2001; Westendrop 2015). V současnosti je střední délka života v nejvyspělejších zemích okolo 80 let. V budoucnosti se potom očekává a je předpokládán pokračující nárůst naděje dožití. Průměrná délka lidského života se má ve světě zvýšit mezi roky 2010 až 2060 u mužů z původních 76,7 let na 84,6 let a u žen z 82,5 na 89,1

Sociální studia / Social Studies 2/2017. S. 9-25. ISSN 1214-813X.

1 Text vznikl díky podpoře projektu specifického výzkumu realizovaného Ústavem populačních studií FSS MU - Zdraví, stárnutí, bydlení a sexualita (MUNI/A/1151/2015). 
let (Pacita 2014). Nerovnosti v naději dožití jsou však výrazné, a to v závislosti na specifických individuálních cestách, které si jedinec zvolí, genderu, rase, etnicitě či sociálním a ekonomickém postavení (Passarino, Rango a Montesanto 2016; Givens et al. 2009). Rozdíly se také projevují na environmentální úrovni, tedy v životních podmínkách, ve kterých člověk žije, či na jeho životním stylu.

I přes existující individuální rozdíly dlouhověkých osob stále přibývá a tato věková skupina se stává v posledních padesáti letech nejrychleji rostoucím věkovým segmentem, a to zejména v evropských populacích a v USA (Andersen-Ranberg et al. 2005; Why population 2015). Podle údajů Českého statistického úr̆adu (Demografická 2014) bylo v roce 2013 v České republice 0,2 milionů osob starších 85 let. Do roku 2060 se potom předpokládá zčtyřnásobení tohoto počtu, a to na 0,8 milionů osob starších 85 let (Projekce 2013). Tyto zvyšující se počty dlouhověkých se týkají všech ekonomicky vyspělých zemí. Celosvětově se předpokládá, že se počet osob ve věku nad 80 let mezi lety 2000 až 2050 skoro zečtyřnásobí, a to na 395 miliónů (Pacita 2014). I přes tento rychlý nárůst je dlouhověkosti jako tématu v sociologii věnována minimální pozornost. Nejstarší senioři často z výběrových šetření vypadávají a my z tohoto důvodu nemáme o jejich potřebách a životech dostatečné znalosti (Westendorp 2015).

Cílem tohoto textu je otevř́it diskuzi o dlouhověkosti v kontextu České republiky. Zatímco v zahraniční literatuře můžeme v posledních letech zaznamenat vzrůstající zájem mnoha vědních oborů o tematiku dlouhověkosti a stoletých (Koch 2010; Bishop et al. 2010; Tomassini 2006), v České republice je jim věnována prozatím minimální pozornost. Otázka nejstarší populace se řeší především v kontextu péče o ni (Dudová 2015; Jeřábek 2009; Nešporová, Svobodová a Vidovićová 2008; Vidovićová a Rabušic 2003) či života v institucionálních zařízeních, a to především v rámci postižení demencí (Holmerová et al. 2007, 2009; Hradcová et al. 2014). V rámci sociologie stárnutí se čeští sociologové a socioložky spíše než pokročilému stáří věnují tzv. třetímu věku či mladému stáří (Hasmanová Marhánková 2013; Petrová Kafková 2013; Sýkorová 2007). Pokud je nám známo, věnoval se otázce houževnatosti ve stáŕí v českém prostředí Švancara (2004: 110-111), který houževnatost (resilience) označuje jako ,pružnost“. Tato pružnost je z jeho pohledu jedním z pěti ,pé“ optimální adaptace, vedle perspektivy, prozíravosti, porozumění pro druhé a potěšení. Nově se pak otázkou houževnatosti zabývají Dubovská a kolektiv (2017), a to prostřednictvím narativní perspektivy. Význam dlouhověkosti především ve formě silných sociálních sítí u žen pak s využitím kvantitativních dat potvrdili Lakomý a Petrová Kafková (2017).

Náš text se proto pokusí existující mezeru české sociologie alespoň částečně vyplnit. Rádi bychom jím v českém prostředí podpořili diskuzi o dlouhověkosti, tedy o relativně zdravých a soběstačných lidech ve vysokém stáří. Na potenciální vysvětlení dlouhověkosti jedněch a různé míry disability jiných stárnoucích se podíváme za pomoci konceptu houževnatosti, který se jeví jako potenciální vysvětlující faktor, se kterým se však překvapivě málo pracuje. Tento původně psychologický koncept přináší jednu z možných příčin existujícího paradoxu, kdy se ženy obecně i přes horší zdraví a sociálně-strukturní faktory, které by měly způsobovat jejich nižší střední délku života, stávají dlouhověké častěji než muži. 


\section{Délka lidského života a její determinanty}

Nejdříve se však zaměřme na to, co vlastně dlouhověkost znamená a jak ji můžeme definovat. $Z$ biologického hlediska je délka lidského života nejasná a odborníci se nemohou na existenci mezní hranice shodnout (Vaupel a Kitowski 2009). Všechny dosud stanovené hranice maximální délky života byly překonány, a ukázaly se tak jako chybné. Dle Vaupel a Kitowski (2009) není jasně empiricky dané, že by se střední délka života nemohla nadále zvyšovat a potenciální nesmrtelnost není stoprocentně nemožná. Tento optimistický pohled je v rozporu se starší teorií J. F. Friese (1980), který byl přesvědčen, že délka lidského života má svůj nepřekročitelný limit, prodlužovat se však bude doba prožitá ve zdraví. Fries tyto myšlenky formuloval $\mathrm{v}$ hypotéze komprese morbidity (compression of morbidity).

Pokud se zaměříme na determinanty ovlivňující délku života, až relativně nedávno začala medicína zkoumat vliv genetické výbavy na dlouhověkost jedince (Passarino, Rango a Montesanto 2016: 1), její vliv však zůstává i přes množství provedených výzkumů nejasný. Existuje určitá shoda, že geny podmiňují délku života pouze z $25 \%$ a zbylých $75 \%$ je dáno vlivem prostředí a životním stylem (Christensen et al. 2006; Passarino, Rango a Montesanto 2016; Robine, Crimmins Horiuchi a Yi 2007). Existují však indicie naznačující, že pokud se jedna generace rodiny dožije vysokého věku, další generace rodiny má velkou pravděpodobnost, že zdědí větší podíl genů dlouhověkosti, které jim zajistí ještě delší život (Šnejdrlová 2008). U takovýchto jedinců má tedy jejich genetická výbava na délku života větší vliv. Dosavadní medicínské výzkumy pak poukazují pouze na zjištění, že století houževnatí jedinci mají v těle mnohem vyšší hladinu antioxidantů, tedy látek, které odstraňují nebezpečné volné radikály, než jedinci, již jsou o třicet let mladší (Ballenger-Browning a Johnson 2010; Sadowska-Bartosz a Bartosz 2014). Tato vysoká hladina anitoxidantů by tak mohla být jedním z potenciálních determinant dlouhověkosti.

Kromě biologických (genetických) faktorů ovlivňujících délku života existují také další determinanty, jež se dají rozdělit na sociální a ekonomické, tedy především životní styl, životní a pracovní prostředí a také péče o vlastní zdraví a úroveň zdravotnictví (Wilkinson, Marmot 2003; Marmot 2005). Životní styl zahrnuje možnosti a kvalitu bydlení, jež jedinec má, jeho různé každodenní návyky, kvalitu a délku spánku, užívání návykových látek, míru a délku př́tomnosti stresu, tělesný pohyb a v neposlední řadě také stravovací návyky (Dimitrová 2007; Čeledová, Kalvach a Čevela 2016). Životní a pracovní prostředí potom zahrnují kvalitu ovzduší, vody, půdy, ale také celkovou kvalitu bydlení, možnosti dopravy a urbanismus krajiny. Poslední skupinou determinantů je péče o zdraví a zdravotnictví, jež zahrnuje úroveň medicínského rozvoje a zdravotnictví, zdravotní politiku, dostupnost zdravotní péče, která je dána právě zase zpětně možnostmi dopravy, a další. Všechny tyto determinanty jsou také ovlivněny sociálními determinanty, které zahrnují nezaměstnanost jedince, vykonávání nebezpečného povolání či globalizaci, které jsou zpětně propojeny s ekonomickými determinanty. Podstatnou se také zdá být typ a intenzita fyzické a psychické aktivity jedince, např́íklad koníčky, sport, četba knih, návštěva kulturních zařízení či čas strávený s práteli nebo blízkými osobami. Výzkumy ukazují, že vyjmenované fyzické a psychické aktivity napomáhají jedinci ke správné funkci mozku, která zajištuje jejich pohodu, nebot' právě špatná funkce mozku, která se vyznačuje častou ztrátu paměti a schopnost přemýšlení, je pro stárnoucí jedince jednou z největších osobních obav (Deary etl al. 2009; Peters 2006; 
Williams, Higgs a Katz 2012), která by dále mohla ovlivnit jejich pohodu a fungování ve stáŕí a vést $\mathrm{k}$ dalším problémům, jež by následně ovlivnily jejich délku života.

\section{Vymezení dlouhověkosti}

V současnosti je dlouhověkost obecně pojímána jako dožití se vyššího věku jedince (Cambridge 2016). Některé studie zabývající se mírou úmrtnosti zjistily, že někteří velmi staří lidé mají nižší míru úmrtnosti, než bylo předvídáno pro jejich věk, a žijí výrazně déle než jejich stejná věková kohorta - a jsou nazýváni dlouhověcí (Smith 1994; Wilson 1994). Avšak není pravda, že dlouhověcí jedinci jsou homogenní skupinou „otužilých a robustních“ a stále žijí v dobré kondici a dobrém zdravotním stavu (Barret 1985). Naopak, dlouhověcí jsou velmi heterogenní skupinou, ve které se některé osoby dožívají sta let v již velmi špatném zdravotním stavu a jiní jedinci se mohou ve stejném věku nacházet v dobrém zdravotním stavu (Barret 1985; Riggs a Millechia 1992). Dožít se sta let tedy automaticky neznamená být v tomto období v dobrém zdravotním a psychickém stavu.

I přestože je ve výzkumech pojem dlouhověkosti využíván, neexistuje úplná shoda na přesném vymezení pojmu dlouhověkost. Např́iklad podle geriatrie je dlouhověkost chápána jako fáze vyvrcholení takzvaného úspěšného stárnutí (Pacovský 1994), tedy oddálení nemoci a nesoběstačnosti jedinců, ale také jejich aktivní zapojení do společnosti, jejich nezávislý život. Hlavním cílem gerontologie a geriatrie by v rámci úspěšného stárnutí potom mělo být funkční zkvalitnění života a dobrá úroveň fungování sociálního, kognitivního a fyzického (Rowe a Kahn 1997). Kalvach s kolegy (2008: 39) chápou dlouhověkost jako „,pozitivní odchylku v průběhu stárnutí a v délce života“. Podle gerontologického pohledu nelze o dlouhověkosti hovořit jako o pouhé periodizaci stáří; převažuje názor, že skupina dlouho žijících osob zastává roli určité subpopulace, která je charakteristická „,zachováním stability celovztažného uspořádání a homeostázy organismu“ (Otová a Kalvach 2004: 93). Podle jiných odborníků není dlouhověkost vrozenou vlastností, ale vytváří se během života skrze faktory, které na jedince působí negativním způsobem. Tímto působením negativních faktorů poté dochází v určité fázi života (cca kolem 85 let) ke zpomalení vymírání věkové kohorty a lidé se následně dožívají vysokého věku (Gjonca, Brockmann a Maier 2000). Toto zjištění je výrazně v souladu s konceptem houževnatosti, jak uvidíme níže.

Pro jiné je však dlouhověkost pojímána naopak pouze jako jedna z chronologicky vymezených etap života. Např́klad Světová zdravotnická organizace (World Health Organization) definuje dlouhověkost jako období od 90. roku výše. Také podle slovníkové definice je dlouhověkost definována jako dožití se vyššího biologického věku nebo také „období lidského života nad devadesát let“ (Hartl 1993; Dictionary.com 2016). Americká geriatrická společnost posouvá hranici dlouhověkosti až na věk 95 let a více. Gjonca, Brockman a Maier (2000) zase naopak ve svém výzkumu věkovou hranici snižují a definují dlouhověkost již od věku 80 let, což spíše odpovídá periodizaci stáří na mladé a starší seniory, tak jak ji vytyčila už Neugarten (1974). V chápání pojmu dlouhověkost tedy nepanuje jasná shoda. Pro účely tohoto textu jej definujeme jako vysoký věk provázený relativním zdravím. 


\section{Dlouhověkost jako výsledek houževnatosti}

Přestože je houževnatost $\mathrm{v}$ oborech gerontologie a geriatrie relativně novým konceptem, v posledních letech je resilience nebo perseverance nejčastěji asociována a zkoumána právě ve vztahu s dlouhověkostí. Pojmy resilience a perserverance bychom mohli do češtiny přeložit jako houževnatost, ale $\mathrm{v}$ jednotlivých článcích, studiích a dalších odborných listech se s těmito pojmy operuje trochu jinak a $\mathrm{v}$ jiném kontextu. Pojem resilience může být obecně chápan jako „zotavení se“ $\mathrm{z}$ negativních důsledků událostí a perseverance jako „udržení si“ rozvoje i přes to, že se jedinec ocitne tváŕí tváŕ nakumulovaným rizikům (Ostwald a Dyer 2011: 50). Perseverance také znamená určitou vytrvalost, a to i přes to, že jedinec setrvává delší časové období v nepř́źznivých životních podmínkách. Lze ji také definovat jako jednu z oblastí, jež ustavuje resilience. $V$ tomto prŕpadě perseverance vyjadřuje schopnost jedince i přes nepř́znivé události zůstat zapojen $\mathrm{v}$ procesu růstu osobnosti, tedy procesu, při kterém dochází $\mathrm{k}$ individuální seberealizaci a který zaručuje pro jedince duševní zdraví a emocionální vyrovnanost (Staudinger, Marsiske a Baltes 1995; Vohora 2011). Pojem resilience je však ve výzkumech používán častěji, proto se na něj v následujících pasážích zaměříme.

Původně byl koncept resilience zaveden ve vývojové a dětské psychologii. Tento koncept vysvětloval, proč se některým dětem a mladistvým i přes nevyhovující prostředí (např́. extrémní chudoba rodiny, mentální onemocnění jednoho nebo obou rodičů, drogová či alkoholová závislost rodičů či násilí) podařilo uspět a vyhnout se ve svém životě jakékoliv patologii (Hardy, Concato a Gill 2004; Ong, Bergamen a Boker 2009; Perkins 2014; Pilowsky, Zybert a Vlahov 2004; Smith a Hayslip 2012).

Postupně se tato perspektiva pozitivní lidské adaptace na různé životní nesnáze a problémy rozš́iřila do výzkumů všech fází života, a to zejména na jedince $\mathrm{v}$ pokročilém stáŕí z pohledu jejich vyrovnávání se s rizikovými událostmi, se kterými se setkávají a musí se s nimi vypořádat (Fry a Keynes 2010). První výzkumy zabývající se houževnatostí v kontextu stárí zjistily, že i přes množství negativních událostí, se kterými se senioři v průběhu života setkali a setkávají (zhoršující se tělesné a duševní zdraví, obtíže při vykonávání každodenních aktivit atd.), zůstávají někteří z nich pozitivně naladěni a otevřeni novým výzvám, jež jim negativní událost přináší (ibid). Také u těchto lidí dochází $\mathrm{k}$ transformaci nepříznivé události do osobnostního růstu. Takovíto lidé se stále učí novým věcem a na základě nových podnětů stále rekonstruují vlastní stárnutí, dochází u nich k neustálému přizpůsobování vlastních životů podle změn a událostí, které je během života potkají a které jim významně ovlivňují životy. Právě tyto jedince můžeme nazývat houževnatými (Cárdenas-Jiménez a LópezDíaz 2011). Tito houževnatí lidé mají dokonce i přes všechny ztráty, strasti a fyzický pokles menší výskyt psychopatologie, tedy trpí nižší mírou duševních poruch než mladší populace obecně (Edwards, Hall a Zautra 2015). Právě prožití a úspěšné překonání negativních událostí přináší vyšší houževnost v seniorském věku než u mladší populace (Nygren 2005; Poon et al. 1992), která dané negativní zkušenosti přicházející se stárnutím prozatím neprožila.

Podle psychologické teorie life-span theory of motivation je zajištění a př́itomnost vyšší houževnatosti u starších osob výsledkem socio-emocionální selektivity (Carsten 1995). Podle této teorie se postupem času jednotlivé časové horizonty smrštují, a tím se s přibývajícím věkem jedinci stávají selektivnější a investují více energie a prostředků do emocionálně smysluplných cílů a aktivit. Tyto emocionální posuny také ovlivňují kognitivní 
procesy, jako jsou vnímání, pozornost, pamět', myšlení, fantazie a další, nebot' stárnutí je spojeno se schopností udržet si v paměti a klást pozornost spíše na pozitivní části získaných informací a zažitých událostí než na ty negativní. Tedy i přes to, že lidé během života prošli a byli vystaveni velmi složitým a negativním životním situacím a událostem, si tyto situace a události často nepamatují, nebo si z nich selektují jen pozitivní části, které určitým způsobem jejich život obohatily a posunuly je dál. Houževnatí senioři také podle této teorie kladou vyšší váhu na emocionální uspokojení, které jim poskytují převážně členové rodiny a další blízcí lidé, a proto $\mathrm{s}$ těmito lidmi tráví většinu svého času. $\mathrm{V}$ tomto případě tak dochází k selektivitě sociálních vztahů, která zajištuje maximalizaci pozitivních emocionálních zážitků, které přispívají k větši pohodě, a naopak minimalizuje potenciální emocionální rizika. Podle teorie socio-emocionální selektivity tak starší jedinci skrze selektivitu efektivně zdokonalují své sociální sítě a jejich sociální partneři uspokojují jejich emocionální potřeby (Carstensen 1992, 1995).

Existují i další definice, které pracují s konceptem houževnatosti, například jako se schopností odrazit se ze stavu nerovnováhy, kterou přináśí nepř́zeň osudu, zpět do stavu rovnováhy a nadále fungovat a pokračovat v normálním životě (Luthar, Cicchetti a Becker 2000; Hildon, Smith, Netuveli a Blane 2008). Houževnatost je také charakterizována jako schopnost převést nepř́zeň osudu do zkušenosti, jež jedince rozvine a posune dál (Edwards, Hall a Zautra 2015; Hengudomsub 2007). Jedná se o schopnost vidět i negativní věci a události s nadějí, humorem nebo jiným druhem „vykoupení“ (Ong, Ewards a Bergeman 2006; McAdams 2006).

Postupně došlo k proměně chápání povahy houževnatosti. Původně byla houževnatost definována jako trvalý osobnostní rys identifikovaný jako nezbytný prvek úspěšného stárnutí (Luthar, Cicchetti a Becker 2000; Perkins 2014). Houževnatost byla chápána jako statická vlastnost, se kterou se již jedinec narodí a nemůže ji získat až v průběhu života. Tato definice houževnatosti však byla př́liš úzká a př́liš omezovala počet lidí, již by mohli být definováni a zařazeni do skupiny úspěšně stárnoucích jedinců (Luthar, Ciccheti Becker 2000). Nověji pak byla houževnatost redefinována jako dynamický proces, jenž může sílit a zeslabovat podle povahy jednotlivých událostí, se kterými se jedinec setkává (Luthar, Cicchetti a Becker 2000; Perkins 2014; Rowe a Kahn 2000; Rutter 2012). Tedy podle této definice není striktně dáno, že jedinec na každou krizovou situaci zareaguje stejným způsobem a za pomoci stejných obranných mechanismů, jako tomu bylo u krizí předchozích, a ne každý jedinec na stejnou krizovou situaci zareaguje stejným způsobem a využije stejných obranných mechanismů. Navíc se tento dynamický a multidimenzionální proces může u každého jedince odlišovat $\mathrm{v}$ několika doménách, jako jsou např́klad individuální sociální kompetence nebo naopak duševní síla, jež jedinci vlastní. Tento proces může být ovlivňován i různými faktory na několika úrovních, tj. na úrovni individuální, úrovni společenských sítí, úrovni lokálního společenství či úrovni větších společenství (Perkins 2014). Houževnost tak spíše než trvalý osobnostní rys začala být chápána jako dynamický a stále se vyvíjející proces každého jedince.

Někteří autoři oproti tomuto individuálnímu přístupu kladou primární důraz spíše na vliv prostředí a nepovažují houževnatost pouze za vlastnost jedince, ale za výsledek vztahu jedince a prostředí neboli vztah mezi individuem a sociálními systémy, kam patř́ rodina, skupiny, organizace, komunity a společnosti. V tomto př́padě mluvíme o environmentální 
perspektivě, která připomíná, že lidský vývoj neprobíhá ve vakuu mimo společnosti, ale jedná se spíše o produkt, který vzniká při neustálém vzájemném styku probíhajícím mezi individui, sociální třídou a kulturním prostředím (Queralt 1996; Germain a Gitterman 1987). Tuto environmentální perspektivu zastává také například Waller (2001), která zároveň upozorňuje, že žádný jedinec není schopen být houževnatý neustále a vůči všem rizikům, což znamená, že pokud jedinec využije obranné mechanismy proti jedné určité negativní události, např́klad při ztrátě práce, neznamená to automaticky, že bude schopný využít své obranné mechanismy při negativní události jiného druhu, např́ílad při smrti partnera. Waller se tak kloní k pojetí houževnatosti jako dynamického procesu.

$\mathrm{Z}$ výše uvedených definic může být houževnatost připodobněna $\mathrm{k}$ regenerační schopnosti, která udržuje jedince $\mathrm{v}$ dobrém zdraví a pohodě, i přesto, že je vystaven tváří $\mathrm{v}$ tvář ztrátám, náhlým změnám, postižení nebo onemocnění. Houževnatost pomáhá při řešení problémů a krizí, jako jsou ztráta blízkého člověka, péče o nemocného/nemocnou partnera/partnerku, a to tím, že nabízí různá řešení a zanechá $\mathrm{v}$ jedinci pocit větší vnitřní síly, než by měl, kdyby se s danými problémy a krizemi nesetkal (Ong, Bergman a Boker 2009). Př́tomnost houževnatosti u seniorů bývá posílena jedincovými vlastnostmi a charakteristikami, mírou sociální a další podpory, sociálními sítěmi, podpůrnými službami, kulturou a spiritualitou, jež jedinec uznává. Masten (1994) hovoří o třech skupinách obecných fenoménů, které jsou s houževnatostí spojené: (1) houževnatí jedinci, již jsou vystaveni riziku, reagují na situaci lépe a jejich výsledné reakce jsou lepší, než jsou očekávané výsledky na dané vystavené riziko, (2) pozitivní adaptace na situaci je u jedince stále prŕtomna i navzdory silně stresující zkušenosti a (3) houževnatost zaručuje vysokou podporu pro návrat do stavu rovnováhy a vyrovnanosti po zažitém traumatu.

Ačkoliv jednotliví autoři hovoří o houževnatosti různými způsoby a za pomoci rozdílných definic, všechny spojuje výsledek ve formě pozitivní adaptace na krizovou situaci. Jedná se o jedincovu adaptaci na situaci, která je mnohem lepší, než se očekává vzhledem $\mathrm{k}$ významnému riziku, kterému je jedinec $\mathrm{v}$ dané situaci vystaven. I přestože se ukazatele pozitivní adaptace ve výzkumech mění, a to $\mathrm{v}$ důsledku rozdílných zkoumaných kontextů v jednotlivých výzkumech, rozdílů mezi zkoumanými populacemi či v odlišné identifikaci jednotlivých rizikových faktorů, jež zkoumané jedince ovlivňují, byly vytvořeny tři hlavní ukazatele houževnatosti: 1) pozitivní výsledek zvládnutí situace navzdory př́tomnému vysokému riziku; 2) udržitelné kompetence navzdory př́tomnosti stresu a 3) úspěšné zotavení se z traumatu (Masten, Best a Garmezy 1990). V rámci těchto třech hlavních ukazatelů se výzkumníci u každého z nich zaměřili na identifikaci takzvaných ochranných zdrojů (protective resources). Jedná se o prostředky, které jedince chrání před všemi krizovými situacemi či nepř́zněmi osudu a které dohromady tvoří individuální houževnatost jedince. Jsou jimi např́klad individuální faktory, které zahrnují temperament jedince či jeho dobré samoregulační schopnosti. Dále jsou to sociální faktory, jako jsou sociální podpora (sociální sítě nabízející jak psychologické, emocionální či materiální zdroje, sociální integrace pomáhající lidem navazovat přátelství a nové vztahy) a socioekonomické postavení ve společnosti (především finanční zajištění jedince, úspory). Poslední skupinou ochranných zdrojů jsou vnějšś podpůrné systémy, kam se řadí různé organizace a pomocné aktivity (denní stacionáře, zájmové kroužky a další) (Antonucci 2001; Hatch 2005; Rutter 1987; Windle 2011). 
Pokud se hovoří o houževnatosti v empirickém zkoumání, je typicky operacionalizována dvěma způsoby. Jednoduchým způsobem, jak lze zjistit prŕitomnost houževnatosti, je využití jedné ze škál měřících houževnatost v rámci psychologického dotazníku (Windle 2011). Př́́kladem takové škály může být škála houževnatosti (resilience scale), jejímž předpokladem je zjištění úrovně osobní houževnatosti jedince s ohledem na pozitivní personální charakteristiky, které zdůrazňují individuální adaptaci na vystavené riziko (Wagnild, Young 1990). Druhým způsobem je operacionalizace houževnatosti pomocí měření dvou nepř́mých indikátorů, a to skrze negativní událost, jíž je zkoumaný vystaven a vypořádává se s ní. Jako negativní událost může být definována řada situací, například zdravotní a duševní problémy, ovdovění, finanční potíže či zhoršení životních podmínek (Hildon et al. 2008, 2010; Netuveli et al. 2008). Adaptace na nepříznivou událost je pak obvykle definována jako zvýšení či zachování subjektivní kvality života v situaci, kdy jedinec čelí alespoň jedné nepř́íznivé události (ibid.).

Přestože se ze všech definic zdá předpoklad, že houževnatost přispívá k dlouhověkosti, zcela logický a je teoreticky dobře ukotvený, empiricky je překvapivě nedostatečně prokázaný. Jednu z mála studií testující houževnatost jako možný indikátor dlouhověkosti realizovali Zeng a Shen (2010). Tito autoři využili dat z čínského longitudinálního výběrového šetření, aby na nich otestovali, zda jsou století jedinci houževnatější než ostatní testované skupiny lidí, jež byly rožrazeny podle věku na 90leté, 80leté a skupinu osob 65letých. Tuto studii také zajímalo, zda faktorem přispívajícím $\mathrm{k}$ jejich výrazné dlouhověkosti je právě houževnatost. Jejich výsledky prokazují, že houževnatost, operacionalizovaná pomocí jedné ze zavedených škál resilience, konkrétně simplified resiliency score, jež zdůrazňuje zvládání a přizpůsobení se životním změnám mezi staršími jedinci, přispívá k dlouhověkosti v průběhu celého života, ale nejvíce se její pozitivní účinek projevuje zejména ve velmi vysokém věku.

Vyšší houževnatost v pokročilém stáŕí byla také potvrzena švédským výzkumem Nygren s kolegy (2005) na vzorku 125 respondentů ve věku 85 a více let. Tato jejich zjištěná přítomnost houževnatosti u respondentů dále pozitivně korelovala s kognitivními funkcemi, fyzickým zdravím a pocitováním vlastního zdraví stejně jako s úspěšným stárnutím. Podle výzkumu Staudinger a kolegů (1995) vlastní houževnatí starší lidé rozrůzněnou strukturu priorit a sebepojetí, jinými slovy mnoho identit, jež jsou rozmanitým způsobem interpretovány. Tyto kognitivní komplexnosti, jak bychom tyto faktory mohli nazvat, se mohou stát jedním z ochranných faktorů, jež konfrontují a řídí celý proces stárnutí a navíc mohou celkově napomáhat zvládání negativních vývojových změn, jež jsou spojeny se zdravotními změnami, ke kterým dochází v průběhu stárnutí. Jinými slovy, kognitivní komplexnosti se promítají do lepšího duševního zdraví (ibid.).

\section{Genderovanost dlouhověkosti}

Typicky je dlouhověkost a houževnatost zkoumána obecně bez ohledu na pohlaví, avšak dlouhověkost je výrazně genderově podmíněna. Pokročilé, vysoké stáří je především zkušeností žen, protože ženy mají v průměru vyšší naději dožití než muži. U dlouhověkých v České republice se konkrétně jedná o poměr mužů a žen 1:4 (Čevela, Kalvach a Čeledová 2012). Tento jev je často vysvětlován rizikovějším chováním mužů, chorobami způsobenými 
nadměrným koư̌ením a pitím alkoholu. Rozdíly v naději dožití jsou také podmíněny genetickými faktory. Tyto rozdíly $\mathrm{v}$ genetice jsou založeny na pohlavním dimorfismu, který ovlivňuje funkci genů ovlivňujících proces stárnutí. Pozitivní vliv na střední délku života u žen má také ženský hormon estrogen, který chrání ženy před kardiovaskulárními chorobami, tedy nejčastější př́íčinou úmrtí (Otová a Kalvach 2004). I přes tyto pozitivní vlivy se u žen projevuje dř́ve a rychleji probíhající geriatrická deteriorace, než je tomu u mužů (Kalvach et al. 2008). Obecně tedy mají ženy předpoklad delš́ího života nežli muži, avšak často oproti mužům v pozdějším období prožívají život v horším zdravotním stavu.

I přes tento statisticky daný nepoměr mužů a žen v pozdějším věku je většina výzkumů o dlouhověkosti zevšeobecňována a spojuje stárnutí žen a mužů dohromady. Ženy se potýkají ve stárí se specifickými, ekonomickými, opatrovnickými a zdravotními otázkami a působí na ně jiné sociálně-strukturní vlivy, než je tomu u mužů (Kinsel 2004a, 2004b). Tyto rozdíly mezi ženami a muži jsou dány historicky skrze rolové uspořádání ve společnosti. A zdá se, že právě ztížené postavení žen ve společnosti vedlo k častějšímu budování a prítomnosti podpůrných mechanismů, které společně vytváří houževnatost (Moen, Dempster-McClain a Williams 1989). Přítomnost houževnatosti u žen je považována za potenciální prríčinu větší pohody, kvality života a také pozitivnějších reakcí na nejrůznější výzvy a změny, jež ženám přináší stárnutí.

Dosavadní provedené kvalitativní výzkumy založené na rozhovorech s ženami identifikovaly jednotlivé významné faktory posilující a formující houževnatost žen (Guldenbrandsen a Walsh 2015; Lyubomirsky, King a Diener 2005; Masten a Obradovic 2006; Neary 1997; Ong et al. 2006; Wagnild a Young 1909; Zautra, Johnson a Davis 2005). Jednalo se o faktory jako ženská angažovanost $\mathrm{v}$ různých spolcích a organizacích, samostatnost žen, vytrvalost, nezávislost, flexibilita, tolerance, odhodlání a pragmatismus. Významnými faktory se také podle provedených výzkumů zdají být sociální podpora, sociální vztahy či denní pozitivní emoce, které poskytují důležitý psychologický oddech. Tento psychologický oddech je velmi důležitý pro obnovování životně důležitých zdrojů, které jsou déle trvající přítomností stresu oslabovány a vyčerpávány (ibid.). Výzkumů zaměřených na jednotlivé podpůrné mechanismy však není mnoho a většina dosavadních se spíše zabývala vdovstvím, které je bráno jako jedna z největších výzev, které stárnutí přináší a se kterou se potýkají s přibývajícím věkem právě převážně ženy.

Ve starším věku je potom smrt, $v$ našem případě budeme hovořit o smrti partnera, jedním z nejčastějších a většinou nejúzkostnějších přechodů $\mathrm{v}$ životě, kterým starší ženy musejí (častěji než muži) čelit a musí se s ním vypořádat (Bonanno et al. 2002; Utz, Caserta and Lund 2011). Po smrti životního partnera u pozůstalých žen dochází ke změnám psychické pohody, větším výskytům smutku, jenž se dělí na žal a deprese. U většiny ovdovělých žen se projevuje žal, který je právě skrze vliv houževnatosti odsunut, a zároveň houževnatost napomáhá vyrovnat se se ztrátou partnera. Ovdovění je tak typickým př́kladem využití houževnatosti. Z psychologického hlediska je toto vyrovnání se smrtí partnera popisováno jako fáze, o které se hovoří jako o fázi přijetí a smírení se s tím, že jedinec zůstal sám, a po tomto smírení dojde $\mathrm{u}$ jedince $\mathrm{k}$ přizpůsobení se světu, ve kterém již zemřelý partner nefiguruje (Vitavera 2013; Firthová, Luffová a Oliviere 2007). Pozůstalé ženy ve fázi smíření využívají různé způsoby zvládání zármutku. Velmi důležitým silným podpůrným mechanismem je 
sociální podpora pozůstalých žen, tedy vztahy s blízkými rodinnými př́slušníky nebo práteli či navázání nových kontaktů (například přátelství s dalšími vdovami). A právě sociální kontakty patří $\mathrm{k}$ jednomu $\mathrm{z}$ typů houževnatosti, zároveň jsou $\mathrm{v}$ jejich zapojování typicky zdatnějš́ ženy než muži (MacDonald 2007; McLaughkin et al. 2010). Vdovství přináší pro ženy nové výzvy a změny, a to jak v rovině emocionálních změn, tak také $\mathrm{v}$ termínech rolových změn. V některých případech se musí ženy naučit novým dovednostem, které před smrtí partnera nepotřebovaly (Fry a Debates 2010). Úmrtí partnera přináší jak zvládání orientované na ztrátu, jež zahrnuje fázi smutku a poklesu plynoucí ze ztráty, tak také zvládání orientované na obnovu, které se snaží dát ztrátě určitý smysl a integrovat tuto ztrátu do života jedince. Oba dva typy zvládání jsou důležité pro úspěšné přizpůsobování novým životním podmínkám (Utz 2006; Hahn et al. 2011; Stroebe a Schut 1999). Mnoho výzkumů, které se zaměřují na vdovství u žen, se zabývá především poklesem jejich blahobytu, tedy zaměřují se na takzvané ztrátově orientované zvládání, které zahrnuje zvýšenou př́tomnost depresí, zvětšující se frustrace a psychosociální problémy, které dále mohou ovlivňovat jak psychické tak fyzické zdraví a psychické chování pozůstalých žen, a právě skrze podpůrné mechanismy, které nabízí houževnatost, mohou ženy tyto negativní faktory překonat (Fry 2001; Bennett 2005; Kraaij, Arensman a Spinhoven 2002; Ostwald a Dyer 2011). V některých př́padech (např. dlouhodobé péči o nemocného či nesoběstačného partnera) byl po ovdovění zaznamenán nárůst blahobytu a větší spokojenosti (Bonnano et al. 2002; Schulz et al. 2003). Ovdovění $v$ těchto prŕpadech přináší ženám možnost rozvoje $\mathrm{v}$ oblastech a aktivitách, na které během péče neměly dostatečné množství času. Právě vypořádání se s ovdověním představuje jeden z typických projevů houževnatosti žen (Carr a Utz 2001; Utz 2006; Feldman, Byles a Beaumont 2000) a podpůrné mechanismy charakteristické pro houževnatost jsou často v tomto procesu klíčové (Fry a Debates 2010; Langer 2004; Ostwald a Dyer 2011). Samozřejmě netvrdíme, že výše popsané formování, postupy a upevňování houževnatosti neprobíhají stejným způsobem i u pozůstalých mužů, avšak většina dosavadních výzkumů se soustředí pouze na výzkumy o ženách vdovách.

Obecně lze výsledky vlivu genderu a stárnutí na houževnatost shrnout tak, že starší dlouhověké ženy jsou obecně houževnatější než mladší ženy a také než starší muži, a to i v př́padech, kdy se jedná o vdovy (Netuveli et al. 2008; Hahn et al. 2011).

\section{Diskuse}

Dlouhověkost se stává jedním z nejvýznamnějších fenoménů 21. století. Zatímco fakt stárnutí populace je už všeobecně známý, dlouhověkosti, jako jedné z jeho součástí, je věnována mnohem menší pozornost. Důvodem může být přetrvávající tendence mluvit o stáří jako o vysoce nákladové sociálně-ekonomické položce, čímž se ospravedlňuje celá anti-welfare politika vyspělých zemí (Vidovićová 2008; Walker 1990). O populačním stárnutí se tak mluví v diskurzu tzv. demografické paniky, tedy perspektivy chápající probíhající demografickou proměnu společnosti jako změnu ohrožující její blahobyt (Mullan 2001; Vidovićová 2008). V kontextu stáŕí jsou pak typicky zvýznamňována dvě témata: jednak potřeba a kvalita péče o nemohoucí seniory a seniorky a téměř v protikladu rétorika aktivního stárnutí zaměřená na „mladé seniory“. Dlouhověkost, tedy relativně soběstačný život v pokročilém stáŕí, je 
zejména $\mathrm{v}$ mediálním diskurzu chápána spíše jako výjimečná situace. A zatímco některé obory věnují značné úsilí odhalení biologických příčin dlouhověkosti některých a disabilitě jiných, pro sociologii stárnutí je toto téma spíše na okraji zájmu. Hlubší znalost každodennosti dlouhověkých, specifik života $\mathrm{v}$ pokročilém byt' relativně zdravém stáŕí nám dosud chybí, a je tak i důležitým námětem pro budoucí výzkum.

V tomto textu jsme ukázali, že pro studium dlouhověkosti může být užitečným koncept houževnatosti (resilience). Přestože definic houževnatosti existuje značné množství, všechny spojuje klíčový společný prvek, a to přítomnost nepříznivé situace či události, na niž jedinci pružně a pozitivně reagují. Podstatou houževnatosti jsou dvě podmínky: (a) vystavení jedince negativní události či zkušenosti a (b) evidence pozitivní adaptace na tyto negativní skutečnosti či zkušenosti (Ong, Bergamen a Boker 2009). Houževnatost je typicky spojována s třemi aspekty; a to sociální podporou, aktivitou a finančním zabezpečením (Clark et al. 2011). Právě tímto souzní koncept houževnatosti jako úspěšné adaptace $\mathrm{v}$ průběhu stárnutí s představou aktivního stárnutí Světové zdravotnické organizace (Active 2002). S konceptem, který se snaží být co nejinkluzivnější a jako kličové chápe bezpečné prostředí a sociální participaci bez jakékoliv hierarchizace méně a více vhodných aktivit (ibid.). Z výše uvedeného bude pro budoucí výzkumy důležité téma houževnatosti v rámci dlouhověkosti více otevřít, nebot' se houževnatost jeví jako potenciální determinant ovlivňující dlouhověkost.

Přestože je koncept houževnatosti v některých oborech už poměrně využívaný, sociologických studií testujících houževnatost jako předpoklad dlouhověkosti je překvapivě málo. Je také dosud nezodpovězenou otázkou, zda je to právě větší houževnatost, která by mohla vysvětlit častější dlouhověkost žen než mužů navzdory jejich větši křehkosti a také nalézt další faktory intervenující do tohoto vztahu. Hlavním cílem následujících výzkumů by se tak mělo stát systematické zkoumání houževnatosti, které by vedlo k podrobnějšímu osvětlení a pochopení jednotlivých procesů, pomocí kterých starší jedinci aktivují a využívají různé zdroje podpůrných mechanismů, které jim napomohou dosáhnout pohody a vést aktivní život navzdory sérii změn, ztrát a výzev, kterým musí čelit v průběhu procesu stárnutí.

\section{Literatura}

Active Ageing: A Policy Framework. 2002. Geneva: World Health Organization.

ANDERSEN-RANBERG, Olaf et al. 2005. „Who Are the Oldest-Old?“ Pp. 35-40 Axel BÖRSCH-SUPAN et al. (eds.). Health, Ageing and Retirement in Europe. First Results from the Survey of Health, Ageing and Retirement in Europe. Mannheim: Research Institute for the Economics of Ageing.

ANTONUCCI, Toni C. 2001. „Social relations: An examination of social networks, social support, and sense of control.“ Pp. 427-453 in James E. BIRREN a Warner K. SCHAIE (eds.). Handbook of the Psychology of Aging. Fifth Edition. San Diego: Academic Press.

BALLENGER-BROWNING, Kara a Douglas C. JOHNSON. 2010. Key facts on resilience. Naval Center for Combat and Operational Stress Control (NCCOSC). Cit. 12. záŕí 2016 (www. nccosc. navy. mil).

BARRET, John C. 1985. „The mortality of centenarians in England and Wales.“ Archives of Gerontology and Geriatrics 4(3): 211-218. 
BENNETT, Kate M. 2005. „Psychological wellbeing in later life: The longitudinal effects of marriage, widowhood and marital status change." International Journal of Geriatric Psychiatry 20: 280-284. BISHOP, Alex J. et al. 2010. „Predicting Happiness among Centenarians.“ Gerontology 56(1): 88-92. BONANNO, George A. et al. 2002. „Resilience to loss and chronic grief: A prospective study from preloss to 18-months postloss.“ Journal of Personality and Social Psychology 83(5): 1150-1164.

Cambridge Dictionary. 2016. „Longevity.“ Cambridge: Cambridge University Press. Cit. 7. listopadu 2016 (http://dictionary.cambridge.org/dictionary/english/longevity).

CARR, Debora a Rebecca UTZ. 2001. „Late-life widowhood in the United States: New directions in research and theory." Ageing International 27(1): 65-88.

CÁRDENAS-JIMÉNEZ, Andrea a Alba L. LÓPEZ-DÍAZ. 2011. „Resiliencia en la vejez.“ Revista de Salud Pública 13(3): 528-540.

CARSTENSEN, Laura L. 1992. „Motivation for social contact across the life span: a theory of socioemotional selectivity." Nebraska Symposium of Motivation 40: 209-254.

CARSTENSEN, Laura L. 1995. „Evidence for a Life-Span Theory of Socioemotinal Selectivity.“ Current Direction in Psychological Science 4(5): 151-156.

CLARK, Phillip G. et al. 2011. „What Do We Know About Resilience in Older Adults? An Exploration of Some Facts, Factors, and Facets."Pp. 51-67 in Barbara RESNICK, Lisa P. GWYTHER a Karen ROBERTO (eds.). Resilience in Aging: Concepts, Research, and Outcomes. New York: Springer.

ČEVELA, Rostislav, Zdeněk KALVACH a Libuše ČELEDOVÁ. 2012. Sociální gerontologie: Východiska ke zdravotni politice a podpoře ve zdraví. Praha: Grada.

DEARY, Ian J. et al. 2009. „Age-associated cognitive decline.“ British Medical Bulletin 92(1): 135-152.

Demografická ročenka České republiky 2013. 2014. Praha: Český statistický úřad. Cit. 23. srpna 2016. (https://www.czso.cz/csu/czso/demograficka-rocenka-ceske-republiky-2013-r9dwy2nt35).

Dictionary.com. 2016. „Longevity.“ Cit. 8. dubna 2016 (http://www.dictionary.com/browse/longevity).

DIMITROVÁ, Michaela. 2007. „Demografické souvislosti stárnutí.“ Naše společnost 1: 24-30.

DUBOVSKÁ, Eva, Vladimír CHRZ, Peter TAVEL, Iva POLÁČKOVÁ ŠOLCOVÁ a Jiří RŮŽIČKA. 2017. „Narrative construction of resilience: stories of older Czech adults.“ Ageing \& Society 37(9): 1849-1873.

DUDOVÁ, Radka. 2015. „Caring for Elderly Parents: A New Commitment of the Third Age.“ Sociologický časopis/Czech Sociological Review 51(6): 903-929.

EDWARDS, Erica S., John HALL a Alex ZAUTRA. 2015. Resilience in Aging. The University of Arizona: Arizona Center on Aging.

FELDMAN, Susan, Julie E. BYLES a Rosie BEAUMONT. 2000. „,Is anybody listening?“ The experiences of widowhood for older Australian women." Journal of Women \& Aging 12(3-4): 155-176.

FIRTHOVÁ, Pam, Gill LUFFOVÁ a David OLIVIERE. 2007. Ztráta, zména a zármutek v kontextu paliativni péče. Brno: Společnost pro odbornou literaturu.

FRIES, Jakob F. 1980. „Aging, natural death, and the compression of morbidity.“ The New England Journal of Medicine 303(3): 130-135.

FRY, Prem S. 2001. „Predictors of health-related quality of life perspectives, self-esteem, and life satisfactions of older adults following spousal loss: An 18-month follow-up study of widows and widowers." The Gerontologist 41(6): 787-798.

FRY, Prem S. a Corey L. M. KEYES. 2010. New Frontiers in Ressilient Aging: Life-Strengths and Well-Being in Late Life. London: Cambridge University Press.

FRY, Prem S. a Dominique L. DEBATS. 2010. „Source of human life-strengths, resilience, and health.“ Pp. 15-59 in Prem S. FRY a Corey L. M. KEYS (eds.). New Frontiers in Resilient Aging: Life-Strengths and Well-Being in Late Life. London: Cambridge University Press.

GERMAIN, Carel B. a Alex GITTERMAN. 1987. „Ecological perspective.“ Pp. 488-499 in Anne MINAHAN (ed.). Encyclopedia of Social Work. 18th Edition. Silver Springs: National Association of Social Workers. 
GIVENS, Jane L. et al. 2009. „Personality Traits of Centenarians“ Offspring.“ Journal of the American Geriatrics Society (57)4: 683-685.

GJONCA, Arjan, Hilke BROCKMANN a Heiner MAIER. 2000. „Old-Age Mortality in Germany prior to and after Reunification." Demographic Research 3.

GULDEBRANDSEN, Cari L. a Christine WALSH. 2015. „Aging and Resilience: Older Women“s Responses to Change and Adversity." Societies 5(4): 760-777.

HAHN, Elizabeth A., Kelly E. CICHY, David M. ALMEIDA a William E. HALEY. 2011. „Time use and well-being in older widows: adaptation and resilience." Women Aging 23(2): 149-159.

HARDY, Susan E., John CONCATO and Thomas M. GILL. 2004. „Resilience of community-dwelling older person." Journal of the American Geriatrics Society 52(2): 257-262.

HARTL, Pavel. 1993. Stručný psychologický slovnik. Praha: Portál.

HASMANOVÁ MARHÁNKOVÁ, Jaroslava 2013. Aktivita jako projekt. Diskurz aktivního stárnutí a jeho odezvy v životech českých seniorů a seniorek. Praha: Sociologické nakladatelství.

HATCH, Stephani L. 2005. „Conceptualizing and identifying cumulative adversity and protective resources: Implications for understanding health inequalities.“ Journals of Gerontology: Series B: Psychological Sciences and Social Sciences 60(2): 130-134.

HENGUDOMSUB, Pornpat. 2007. „Resilience in later life.“ Thai Pharmaceutical and Health Science Journal 2(1): 115-123.

HILDON, Zoe, Scott M. MONTGOMERY, David BLANE, Richard D. WIGGINS a Gopalakrishnan NETUVELI. 2010. „Examining resilience of quality of life in the face of health-related and psychosocial adversity at older ages: What is 'right' about the way we age?" Gerontologist 50(1): 36-47.

HILDON, Zoe, Glenn SMITH, Gopalakrishnan NETUVELI a David BLANE. 2008. „Understanding adversity and resilience at older ages.“ Sociology of Health \& Illness 30(5): 726-740.

HOLMEROVÁ, Iva et al. 2007. „Dignity and Palliative Care in Dementia.“ The Journal of Nutrition, Health \& Aging 11(6): 489-494.

HOLMEROVÁ, Iva et al. 2009. „Effect of the Exercise Dance for Seniors (EXDASE) Program on Lower-Body Functioning Among Institutionalized Older Adults." Journal of Aging and Health 22(1): $106-119$.

HRADCOVÁ, Dana, Lucie HÁJKOVÁ, Martina MÁTLOVÁ, Hana VAŇKOVÁ a Iva HOLMEROVÁ. 2014. „Quality of care for people with dementia in residential care settings and the 'Vážka' Quality Certification System of the Czech Alzheimer Society“. European Geriatric Medicine 5(6): 430-434.

CHRISTENSEN, Kaare, Thomas E. JOHNSON a James W. VAUPEL. 2006. „The quest for genetic determinants of human longevity: challenges and insights." Nature Reviews Genetics 7(6): 436-448.

JEŘÁBEK, Hynek. 2009. „Rodinná péče o seniory jako 'práce z lásky’: nové argumenty.“ Sociologický časopis/Czech Sociological Review 45(2): 243-266.

KALVACH, Zdeněk, Roman JIRÁK, Helena ZAVÁZALOVÁ a Iva HOLMEROVÁ. 2008. Geriatrické syndromy a geriatrický pacient. Praha: Grada.

KINSEL, Beth I. 2004a. Older Women and Resilience: A Qualitative Study of Adaption. Ohio: School of The Ohio State University.

KINSEL, Beth I. 2004b. „Resilience as Adaption in Older Women.“ Journal of Women Anging 17(3): 23-39.

KOCH, Tina, Rose TURNER, Pam SMITH a Nimi HUTNIK. 2010. „Storytelling reveals the active, positive lives of centenarians.“ Nursing Older People 22(8): 31-36.

KRAAIJ, Vivian, Ella ARENSMAN a Philip SPINHOVEN. 2002. „Negative life events and depression in elderly persons: A meta-analysis.“ The Journal of Gerontology: Medical Sciences 57(1): 87-94.

LAKOMÝ, Martin a Marcela PETROVÁ KAFKOVÁ. 2017. „Resilience as a Factor of Longevity and Gender Differences in Its Effects." Sociologický časopis/Czech Sociological Review 53(3): 369-392. 
LANGER, Nieli. 2004. „Resiliency and spirituality: Foundations of strengths perspective counseling with the elderly." Educational Gerontology 30(7): 611-617.

LUTHAR, Suniya S., Dante CICCHETTI a Bronwyn BECKER. 2000. „The construct of resilience: A critical evaluation and guidelines for future work." Child Development 71(3): 543-562.

LYUBOMIRSKY, Sonja, Laura KING a Ed DIENER. 2005. „The benefits of frequent positive affect: Does happiness lead to success?" Psychological Bulletin 131: 803-855.

MASTEN, Ann S. 1994. „Resilience in individual development: Successful adaptation despite risk and adversity.“ Pp. 3-25 in Margaret C. WANG a Edmund W. GORDON (eds.). Educational resilience in inner-city America: Challenges and prospects. Hillsdale: Lawrence Erlbaum Associates.

MASTEN, Ann S. a Jelena OBRADOVIC. 2006. „Competence and resilience in development.“ Annals of the New York Academy of Sciences 1094: 13-27.

MASTEN, Ann S., Karin M. BEST a Norman GARMEZY. 1990. „Resilience and development: Contributions from the study of children who overcome adversity." Development and Psychopathology 2(4): 425-444.

MacDONALD, Maurice. 2007. "Social Support for Centenarians: Health, Psychological Well-Being, and Longevity." Annual Review of Gerontology \& Geriatrics 27: 107-127.

McADAMS, Dan P. 2001. The person: An integrated introduction to personality psychology. New York: Harcourt.

McLAUGHLIN, Deidre, Dimitrios VAGENAS, Nancy A. PACHANA, Nelufa BEGUM a Annette DOBSON. 2010. "Gender Differences in Social Network Size and Satisfaction in Adults in Their 70s." Journal of Health Psychology 15(5): 671-679.

MOEN, Phyllis, Donna DEMPSTER-McCLAIN a Robin M. WILLIAMS. 1989. „Social Integration and Longevity: An Event History Analysis of Women“s Roles and Resilience.“ American Sociological Review 54(4): 635-647.

MULLAN, Phil. 2001. The Imaginary Time Bomb: Why an Ageing Population Is Not a Social Problem. London: I.B.Tauris.

NEARY, Susan R. 1997. Room to maneuver: Preserving choice in resilient old age. Doctoral dissertation. Boston: Boston College.

NEŠPOROVÁ, Olga, Kamila SVOBODOVÁ a Lucie VIDOVIĆOVÁ. 2008. Zajištění potřeb seniorů $s$ di̊razem na roli nestátního sektoru. Praha: Výzkumný ústav práce a sociálních věcí.

NETUVELI, Gopalakrishnan et al. 2008. „Mental health and resilience at older ages: bouncing back after adversity in the British Household Panel Survey." Journal of Epidemiology and Community Health 62: 987-991.

NEUGARTEN, Bernice L. 1974. „Age Groups in American Society and the Rise of the Young-Old.“ The ANNALS of the American Academy of Political and Social Science 415(1):187-198.

NYGREN, Björn et al. 2005. „Resilience, sense of coherence, purpose in life and self-transcendence in relation to perceived physical and mental health among the oldest old." Aging and Mental Health 9(4): 354-362.

ONG, Anthony, D., Cindy S. BERGEMAN, Toni L. BISCONTI a Kimberly A. WALLACE. 2006. „Psychological resilience, positive emotions, and successful adaptation to stress in later life." Journal of Personality and Social Psychology 91(4): 730-749.

ONG, Anthony D., Cindy S. BERGEMAN a Steven M. BOKER. 2009. „Resilience Comes of Age: Defining Features in Later Adulthood.“ Journal of Personality 77(6): 1777-1804.

ONG, Anthony D., Lisa EDWARD a Cindy S. BERGEMAN. 2006. „Hope as a source of resilience in later adulthood.“ Personality and Individual Differences 41(7): 1263-1273.

OSTWALD, Sharon a Carmel DYER. 2011. „Fostering resilience, promoting health and preventing disease in older adults. “ Pp. 48-86 in Ian STUART-HAMILTON (ed.). An Introduction to Gerontology. Cambridge: Cambridge University Press. 
OTOVÁ, Berta a Zdeněk KALVACH. 2004. „Odchylky a poruchy stárnutí a genetická dispozice některých chorob stáŕí.“ Pp. 90-98 in Zdeněk KALVACH, Zdeněk ZADÁK, Roman JIRÁK, Helena ZAVÁZALOVÁ, Petr SUCHARDA a kol. (eds.). Geriatrie a gerontologie. Praha: Grada.

PACITA. 2014. „Statistika: Světová populace rychle stárne.“ PACITA. Cit. 5. května 2016 (http://wp6. pacitaproject.eu/statistika/).

PACOVSKÝ, Vladimír. 1994. Geriatrie: Geriatrická diagnostika. Praha: Scientia Medica.

PASSARINO, Giuseppe, Francesco DE RANGO a Alberto MONTESANTO. 2016. „Human longevity: Genetics or Lifestyle? It takes two to tango.“ Immunity \& Ageing [online] 13(12). Cit. 5. května 2016 (https://www.ncbi.nlm.nih.gov/pmc/articles/PMC4822264/).

PERKINS, Molly M. 2014. „Resilience in Later Life: Emerging Trends and Future Directions.“ The Gerontologist 54(1): 138-142.

PETERS, Ruth. 2006. „Ageing and the brain.“ Postgraduate Medical Journal 82(964): 84-88.

PETROVÁ KAFKOVÁ, Marcela. 2013. Šedivéjici hodnoty? Aktivita jako dominantní způsob stárnutí. Brno: Munipress.

PILOWSKY, Daniel J., Patricia A. ZYBERT a David VLAHOV. 2004. „Resilient children of injection drug users.“ The America Academy of Child Adolescence Psychiatry 43(11): 1372-1379.

POON Leonard W. et al. 1992. „The Georgia Centenarian Study: A Study of Longevity and Survival of the Oldest Old." International Journal of Aging and Human Development 34(1): 1-17.

Projekce obyvatelstva České republiky do roku 2100. 2013. Praha: Český statistický úřad. Cit. 4. března 2014 (http://www.czso.cz/csu/2013edicniplan.nsf/publ/4020-13-n_2013).

QUERALT, Magaly. 1996. The social environment and human behavior: A diversity perspective. Boston: Allyn and Bacon.

RIGGS, Jack E. a Ronald J. MILLECCHIA. 1992. „Mortality among the elderly in the U.S., 1956-1987: Demonstration of the upper boundary to Gompertzian mortality.“ Mechanisms of Ageing and Development 62(2): 191-199.

RILEY, James C. 2001. Rising Life Expectancy: A Global History. London: Cambridge University Press. ROBINE, Jean-Marie, Eileen M. CRIMMINS, Shiro HORIUCHI a Zeng YI. 2007. Human Longevity, Individual Life Duration, and The Growth of The Oldest-Old Population. Dordrecht: Springer.

ROWE, John W. a Robert L. KAHN. 1997. „Successful aging.“ Gerontologist 37(4): 433-440.

ROWE, John W. a Robert L. KAHN. 2000. „Successful aging and disease prevention.“ Renal Replacement Therapy 7(1): 70-77.

RUTTER, Michael. 1987. „Parental mental disorder as a psychiatric risk factor.“ Pp. 647-663 in Robert E. HALES a Allen J. FRANCES (eds.). American Psychiatric Association Annual Review. Volume 6. Washington: American Psychiatric Association.

RUTTER, Michael. 2012. „Resilience as a dynamic concept.“ Development and Psychopathology 24(2): 335-344.

SADOWSKA-BARTOSZ Izabela a Grzegorz BARTOSZ. 2014. „Effect of antioxidants supplementation on aging and longevity." BioMed research international [online]. 2014. Cit. 7. března 2016 (http://www.ncbi.nlm.nih.gov/pubmed/24783202).

SCHULZ, Richard et al. 2003. „End of life care and the effects of bereavement on family caregivers of persons with dementia.“ New England Journal of Medicine 349(20): 1936-1942.

STAUDINGER, Ursula M., Michael MARSISKE a Paul B. BALTES. 1995. „Resilience and reserve capacity in later adulthood: Potentials and limits of development across the life span." Pp. 801-847 in Dante CICCHETTI a Donald J. COHEN (eds.). Developmental psychopathology. Volume 2: Risk, disorder, and adaptation. New York: Wiley.

STROEBE, Margaret a Henk SCHUT. 1999. „The dual process model of coping with bereavement: Rationale and description." Death Studies 23(1): 197-224. 
SÝKOROVÁ, Dana. 2007. Autonomie ve stáři. Kapitoly z gerontosociologie. Praha: Sociologické nakladatelství.

ŠNEJDRLOVÁ, Michaela a Zdeněk KALVACH. 2008. „Funkční stav v pokročilém stáří a genetická dispozice k dlouhověkosti.“ Medicína pro praxi 5(4): 157-159.

ŠVANCARA, Josef. 2004. „Psychické involuce a psychologické aspekty adaptace ve stáŕí.“Pp. 103-115 in Zdeněk KALVACH, Zdeněk ZADÁK, Roman JIRÁK, Helena ZAVÁZALOVÁ, Petr SUCHARDA a kol. (eds.). Geriatrie a gerontologie. Praha: Grada.

TOMASSINI, Cecilia. 2006. „The oldest old in Great Britain: change over the last 20 years.“ Population Trends 123: 32-40.

UTZ, Rebecca. 2006. „Economic and practical adjustments to late life spousal loss.“ Pp. 167-192 in Debora CARR, Randolph M. NESSE a Camille B. WORTMAN (eds.) Spousal bereavement in late life. New York: Springer.

UTZ, Rebecca L. et al. 2004. „The daily consequences of widowhood: The role of gender and intergenerational transfers on subsequent housework performance." Journal of Family Issues 25(5): 683-712.

UTZ, Rebeca, Michaela CASERTA a Dale LUND. 2011. „Grief, depressive symptoms, and physical health among recently bereaved spouses.“ The Gerontologist 52(4): 460-471.

VAUPEL James W. a Kristin K. G. von KISTOWSKI. 2009. „Plasticita průměrné délky života a její důsledky.“ Pp. 39-60 in Peter GRUSS (ed.). Perspektivy stárnutí z pohledu psychologie celoživotního stárnutí. Praha: Portál.

VIDOVIĆOVÁ, Lucie. 2008. Stárnutí, věk a diskriminace: nové souvislosti. Brno: Mezinárodní politologický ústav.

VIDOVIĆOVÁ, Lucie a Ladislav RABUŠIC. 2003. Senioři a opatřeni v oblasti stárnutí v pohledu české veřejnosti. Zpráva z empirického výzkumu. Praha: Výzkumný ústav práce a sociálních věcí.

VITAVERA. 2013. „Proces truchlení při ztrátě blízké osoby.“ Vitavera. Cit. 24. listopadu 2016 (http://vitavera.denik.cz/clanky/proces-truchleni-pri-ztrate-blizke-osoby/).

VOHORA, Reena. 2011. Resilience in later life. Doctoral dissertation. Oxford: Oxford University.

WAGNILD, Gail a Heather M. YOUNG. 1990. „Resilience among older women.“ Image: Journal of Nursing Scholarship 22(4): 252-255.

WALKER, Alan. 1990. „The Economic ‘Burden’ of Ageing and the Prospect of Intergenerational Conflict.“ Ageing \& Society 10(4): 377-396.

WALLER, Margaret A. 2001. „Resilience in Ecosystemic Context: Evolution of the Concept.“ American Journal of Orthopsychiatry 71(3): 290-297.

WESTENDROP, Rudi. 2015. „Rethink old age.“ Pp. 16-17 in Susan DAVISON, James GOODWIN a Phil ROSSALL (eds.). Improving Later Life. Understanding Oldest Old Ageing. London: Age UK.

Why Population Aging Matter: A Global Perspective. 2015. National Institute on Aging, National Institutes of Health, U. S. Department of Health and Human Services. Cit. 6. května 2016 (https:// www.nia.nih.gov/sites/default/files/2017-06/WPAM.pdf).

WILKINSON, Richard a Michael MARMOT. 2003. Social Determinants of Health: The Solid Facts. Copenhagen: World Health Organization.

WILLIAMS, Simon J., Paul HIGGS a Stephen KATZ. 2012. „Neuroculture, active ageing and the 'older brain': problems, promises and prospects." Sociology of Health and Illness 34(1): 64-78.

WILSON, David L. 1994. „The analysis of survival (mortality) data: Fitting Gompertz, Weibull, and logistic functions." Mechanisms of Ageing and Development 74(1-2): 15-33.

WINDLE, Gill. 2011. „What is resilience? A systematic review and concept analysis.“ Clinical Gerontology 21(2): 152-169.

ZAUTRA, Alex J., Lisa M. JOHNSON a Mary C. DAVIS. 2005. „Positive affect as a source of resilience for women in chronic pain. “ Journal of Consulting and Clinical Psychology 73(2): 212-220. 
ZENG Yi a Ke SHEN 2010. „Resilience Significantly Contributes to Exceptional Longevity.“ Current Gerontology and Geriatrics Research. [online]. Cit. 5. května 2016 (https://www.hindawi.com/ journals/cggr/2010/525693/ ).

\section{Autorky}

Michaela Honelová je doktorandka sociologie na Fakultě sociálních studií Masarykovy univerzity. Ve své magisterské práci se zabývala tématem anti-ageingu v prostředí žen vykonávající práci kosmetiček. V současnosti se zajímá také o problematiku genderu ve společnosti.

Kontakt: 397582@mail.muni.cz

Marcela Petrová Kafková je socioložka a výzkumnice Ústavu populačních studií Fakulty sociálních studií Masarykovy univerzity. Dlouhodobě se věnuje oblasti sociologie stárnutí a sociální gerontologie. Její výzkumný zájem se soustředí především na oblast populačního stárnutí, koncept aktivního stárnutí a jeho reprezentací a také environmentální gerontologii. Kontakt: kafkova@fss.muni.cz 